\title{
DRAKOLOGIA STAROŻYTNA. MOTYW SMOKA W LITERATURZE POZABIBLIJNEJ
}

Smok towarzyszył ludziom od zarania dziejów, przybierając różne kształty, pełniąc różne role, fascynując kolejne pokolenia swoją majestatycznością, siłą czy umiejętnościami. Nie ma bowiem mitologii, która nie miałaby opowieści na temat tych istot. Od chińskich lungów do skandynawskiego Fafnira, motyw ten był szeroko wykorzystywany zarówno przez artystów, pisarzy i do dziś z chęcią sięgają po niego różnego rodzaju twórcy. Mimo to smok wciąż pozostaje stworem nieuchwytnym, zmiennym, wymyka się próbom zdefiniowania. Jak bowiem przedstawić coś, co wciąż jeszcze podlega ewolucji? Mimo że nie mieści się w ramach dzisiejszego świata postępu, nauki i techniki, skutecznie opiera się próbom odesłania do lamusa czy eliminacji. Wpisał się bowiem na stałe w sposób myślenia ludzi, ich postrzeganie świata, poruszając do głębi serca i inspirując do tworzenia coraz to nowych opowieści czy obrazów (także ruchomych). Z tego wynika chęć zbadania tego fenomenu, poszukiwania jego korzeni, sięgnięcia do najstarszych pokładów wiedzy, jaką mieli na jego temat starożytni, a nawet stworzenia nowej dyscypliny nauki - drakologii - pragnącej zebrać i metodycznie opracować cały ten dorobek kulturowy.

Do tej pory wielu ludzi próbowało zmierzyć się z tym zadaniem, czego rezultatem są dzieła o różnej wartości naukowej. Nie sposób nie zauważyć, charakteryzując literaturę przedmiotu, że problematyka smoka pojawia się jako jeden z tematów przy opracowywaniu mitów różnych kultur. Nie brakuje jednak publikacji w całości poświęconych tej tematyce, jednak w większości mają one charakter pseudonaukowy (skierowane zwłaszcza do młodszych odbiorców ${ }^{1}$ )

1 D.A. S t e e r (red.), Doktora Ernesta Drake'a Kompendium Wiedzy Smokologicznej, tłum. P. Z a r a w s k a, Chiny 2009. I inne z tej serii: E. D r a k e, Smokologia. 
lub popularnonaukowy (różnej wartości). ${ }^{2}$ Spośród stricte naukowych pozycji wymienić można jedynie dzieła Marka Sikorskiego: Smoki i smokobójstwo oraz Daniela Ogdena - Drakon: Dragon Myth and Serpent Cult in the Greek and Roman worlds. ${ }^{3}$ Jednak w przypadku literatury przedmiotu podstawowym problemem jest nie jej ilość lecz jakość. Nie można się bowiem oprzeć wrażeniu, że wielu badaczy popełnia podstawowe błędy metodologiczne: powtarza pewne błędne opinie, stawia tezę, zanim przebada fakty, co prowadzi do dostosowywania danych, by zgadzały się z teorią, i pomijania tych, które są z nią sprzeczne.

Najlepszym tego przykładem jest przedstawianie biblijnej wizji smoka, która, jako że Księga ta jest jednym z najważniejszych fundamentów współczesnej kultury europejskiej, nie może być pominięta przez żadnego badacza zajmującego się interesującym nas motywem. Większość jednak ogranicza się do najsłynniejszego fragmentu o smoku - Apokalipsy (Ap 12,3-9), nieliczni odwołują się także do kilku innych tekstów, patrząc na nie przez pryzmat tego tekstu lub późniejszych wierzeń. Jednakże przedstawienie smoka takim, jaki wyłania się z lektury całości Pisma Świętego, musi pozostać kwestią osobnej pracy... Niniejsza ma na celu sięgnięcie do korzeni - kultury tych ludzi, którzy spisywali Biblię, ich wyobrażeń i pojęć oraz tego wszystkiego, z czym mogli się zetknąć lub na czym mogli się oprzeć, tworząc własne dzieło. A zatem dąży do odpowiedzi na pytania: Kim

Wielka księga smoków, tłum. P. Z a r a w s k a, Chiny 2007; D.A. S t e e r (red.), Smokologia. Smok Mroźnik, tłum. P. Z a r a w s a, Chiny 2008.

2 B.G. S a 1 a, Księga Smoków Polskich, Lesko 2014; G. R a g a c h e, Mity i legendy. Smoki, tłum. P. L a t k o, Wrocław 1992; R.A. B o u 1 a y, Flying Serpents and Dragons. The story of Man's Reptilian Past. The Evidence that We are the Children of Ancient Astronauts and Serpent-Gods, Escondido, California 1999; E. I n g e rs o 11, Dragons and Dragon Lore, New York 1928; Z. D r a p e 11 a, Od Lewiatana do Jormungarda. Rzecz o potworach morskich, ludziach z Morza i duchach wód, Gdańsk 1976.

3 Pomijam w wykazie różnego rodzaju pozycje encyklopedyczne czy słownikowe tj. C. R o s e, Giants, Monsters, and Dragons. An Encyclopedia of Folklore, Legend, and Myth, New York 2001. 
lub czym był smok dla starożytnych kultur Basenu Morza Śródziemnego? Jak postrzegano go w czasach starożytnych?

Podstawą źródłową pracy są przede wszystkim teksty starożytnych mitografów, przyrodników, geografów czy historyków. Podstawową trudnością, którą należało pokonać, było dotarcie do starożytnych źródeł. Chociaż bowiem wielu badaczy podejmowało się opracowania mitów tamtego regionu i czasów, nieliczni podają źródła, z których czerpią informacje (ma to miejsce zwłaszcza wśród prac dotyczących mitów greckich) lub nie są precyzyjni - pomijając oznaczenia poszczególnych rozdziałów (czy tabliczek w przypadku źródeł bliskowschodnich) i wersów, utrudniając zarówno znalezienie tych fragmentów jak i porównanie $\mathrm{z}$ innymi tłumaczeniami. Istnieją także poważne braki w tłumaczeniach niektórych dzieł na język polski albo nie były one nigdy przełożone, albo przekłady są niedostępne, albo przetłumaczono tylko fragmenty na potrzeby danego opracowania. Sporą pomocą okazują się różnego rodzaju bazy tekstów starożytnych w językach oryginalnych i tłumaczeniu angielskim np. Perseus Digital Library czy The Electronic Text Corpus of Sumerian Literature; oraz zdigitalizowane przez Internet Archive książki angielskie, w tym i tłumaczenia i opracowania.

Podstawową kwestią metody badawczej, którą należy poruszyć, jest próba przedstawienia takiej definicji smoka, która umożliwiałaby dokonanie selekcji spośród panteonu mitycznych stworzeń, bestii i potworów, takich, które moglibyśmy zaliczyć do kategorii smoków. Nie w każdym języku bowiem istnieje osobne pojęcie dla tego rodzaju stworzeń lub nie jest ono dość precyzyjne (odnosi się bowiem zarówno do smoków jak i węży). Także ikonografia pozostawia w tym względzie wiele wątpliwości. Dlatego też przyjmujemy, że smokiem nazywamy każdą istotę, która ma wężowe cechy oraz inne, odróżniające ją od zwyczajnych zwierząt.

Z braku możliwości przedstawienia opisu każdego smoka, skupimy się na problematycznym zestawieniu funkcjonowania tego motywu, wskazując podobieństwa i różnice między rolą, jaką miał odegrać w różnych przedstawieniach. Tak więc właściwy wydaje 
się podział niniejszego artykułu na dwie główne części dotyczące sposobu przedstawienia smoków oraz ról, jakie odgrywają.

Należy jeszcze określić obszar naszych badań, albowiem wiele kultur rozwinęło się w starożytności, wiele mogło mieć wpływ na proces kształtowania się biblijnego obrazu smoka, ponieważ każda na swój specyficzny sposób przedstawiała te istoty. Biorąc to pod uwagę, konieczne okazało się odniesienie do myśli greckiej (przejętej i rozwiniętej nieco przez Rzymian), egipskiej i bliskowschodniej z pominięciem jednak dorobku samych Izraelitów.

\section{Charakterystyka smoków}

Smok, w zależności od czasu, kultury i mitu, ma inne upodobania, zwyczaje, umiejętności, zachowania i cechy zewnętrzne. Nie ma zatem jednego uniwersalnego wzorca. ${ }^{4}$ Jednak pewne elementy pojawiają się w opisach częściej niż inne, podczas gdy te drugie stanowią ewenement. Warto zatem bliżej przyjrzeć się charakterystyce tych istot, nie tylko pod względem wyglądu i budowy, ale i obyczajów, umiejętności, miejsc występowania, pochodzenia i pośmiertnych losów.

\section{Jak wygląda smok?}

Najbardziej charakterystyczną cechą wyglądu smoka jest jego powiązanie $\mathrm{z}$ wężami (rzadziej z innymi gadami ${ }^{5}$ ). $\mathrm{Z}$ tym, że niekiedy jest to element ledwo zauważalny - jak łuski (Anzu, Nin-tu, bezimienna wybranka Ereszkigal ${ }^{6}$ ) czy wąż zamiast ogona (Sfinks,

4 M. G i e r s z e w s k a, Smoki jako istoty mieszane. Funkcjonowanie w literaturze greckiej i rzymskiej, Symbolae Philologorum Posnaniensium graecae et latinae XXII/1, s. 169-170.

5 Wyjątkiem jest tu Am-mutu, która ma gadzie cechy, lecz nie węża a krokodyla. A. N i w i ńs k i, Mity i symbole Starożytnego Egiptu, Warszawa 2001, s. 282-283 (dalej: AN).

${ }_{6}$ Lugalbanda z Unug, w: Eposy sumeryjskie, tłum. K. S z a r z y ń s k a, Antologia literatury mezopotamskiej, Warszawa 2003, s. 43 (dalej: ES); Tabliczka DD, 
Szes-szes ${ }^{7}$ ) - innym razem dominujący - smok jest wężem wyróżniającym się od zwykłych przedstawicieli fauny nietypową cechą lub umiejętnościami. Do tych szczególnych właściwości należy rozmiar $\left(\right.$ Smok kolchidzki, Apopis ${ }^{8}$ ), posiadanie więcej niż jednej głowy (dwugłowy Ter, trzygłowy Menmenut i Neheb-Kau; pięciogłowy Ash-hrau; siedmiogłowy Jam i Litan; dziewięcio-, pięćdziesięcio- lub stugłowa Hydra i stugłowy Tyfon ${ }^{9}$ i Ladon ${ }^{10}$ ), także przedstawicieli zwierząt innego gatunku (np. Kampe ${ }^{11}$ ). Ta hybrydowość obejmuje jednak nie tylko dodatkowe łby bestii, ale także inne części ciała (najczęściej kły, brody, grzebienie na głowie, nogi i skrzydła), należące do dzików, lwów, wilków, ryb, lampartów, baranów, kóz, psów, skorpionów, krokodyli, hipopotamów oraz ludzi ${ }^{12}$. Zdarzały się jednak

1-14, w: The devils and evil spirits of Babylonia, being babylonian and assyrian incantations against the demons, ghouls, vampires, hobgoblins, ghosts, and kindred evil spirits, which attack mankind, t. II: Fever sickness and headache etc., tłum. R. C a m p be 11 Th o m p s o n, Luzac's Semitic Text and Translation Series XV, London 1904, s. 146-149. Tabliczka DD, 26-41, w: tamże, s. 150-151.

7 M. P i e tr z y k o w s k i, Mitologia starożytnej Grecji, Warszawa 1985, s. 214. E.A. Wa 11 is B udg e, The Book of Gates, London 1905, s. 244.

8 P ind a r, Pythian Odes 4.242-249, http://www.perseus.tufts.edu/hopper/tex $\mathrm{t}$ ?doc $=$ Perseus \%3Atext\%3A1999.01.0162\%3Abook\%3DP.\%3Apoem\%3D4 (dostęp: 28 XII 2015). Księga Amduat, siódma godzina nocy, w: AN, s. 143.

9 E.A. Wallis Budge, Księga Amduat, Staroegipskie zaświaty, tłum. D. S t a c h u r a, Sandomierz 2013, s. 40-58 (dalej: KA); por. AN, s. 141. Cykl Baala z Ugarit, tłum. Ł. T o b o ł a, Kraków 2008, s. 137, 193 (dalej: KTU); S i m o n i d e s, Fragments, 569, w: Greek Lyric III Stesichorud, Ibycus, Simonides, and others, tłum. D. A. C a m p b e 11, Cambridge-London 1991, s. 455; H e z j o d, Teogonia, 820-835, http://archeos.pl/forum/index.php?topic=4853.0 (dostęp: $27 \mathrm{X}$ 2014).

10 A p ollo d o r u s, Library, 2.5.11, http://www.perseus.tufts.edu/hopper/te $\mathrm{xt}$ ?doc $=$ Perseus:text:1999.01.0022:text $=$ Library:book=2:chapter $=5 \&$ highlight $=$ la don (dostęp: 27 X 2014) (dalej: AL). Aczkolwiek w sztuce przedstawiany był tylko $\mathrm{z}$ jedną głową.

${ }^{11}$ Nonnus of Panopolis, Dionysiaca, t. II: Books XVI-XXXV, tłum. W. H. D. R o u s e, Cambridge, Ma-London 1911, 18.236-264.

12 Tamże, 18.236-264; A e $1 \mathrm{i}$ a n, On the characteristics of animals with an English translation by A. F. Scholfield, Books VI-XI, Cambridge, Ma-London 1959, 16.18; AN, s. 282-283; AL, 2.5; H e z j o d, Teogonia, 303-324. 
cechy nietypowe dla żyjących zwierząt (czy też właściwie wyolbrzymione), należą do nich oślepiające blaskiem oczy (Smok kolchidzki, Tyfon, Anubis ${ }^{13}$ ), grzebienie (indyjskie smoki górskie ${ }^{14}$ ) lub ciała połyskujące własnym światłem $\left(\mathrm{Asag}^{15}\right.$ ) albo odbijające promienie Słońca przez metaliczny połysk łusek (indyjskie smoki pogórskie i górskie, Gorgony, Hydra, bezimienny smok z Papirusu $1115^{16}$ ).

\section{Niezwykłe umiejętności smoków}

Śmiercionośność jest najczęściej podkreślaną cechą tego rodzaju istot, których ofiarą padali nie tylko ludzie, ptaki, bydło ale nawet słonie. ${ }^{17}$ Liczne przekazy różnią się jednak w sposobie zabijania przez smoki. Oprócz typowego dla węży zatrucia jadem, ${ }^{18}$ ewentualnie duszenia - z tą różnicą, że zamiast zmiażdżenia, przez silny uścisk splotów całego ciała, sądzono niekiedy, że wieszają ofiarę na drzewie dzięki pojedynczej pętli wokół szyi ${ }^{19}$ - smoki miały do dyspozycji także kły i pazury, ${ }^{20}$ rzadziej trujący oddech ${ }^{21}$ (niektórzy twierdzą

$13 \mathrm{O}$ w i d i u s z, Heroidy, 12.101, http://www.perseus.tufts.edu/hopper/text?doc =Perseus\%3Atext\%3A1999.02.0085\%3Apoem\%3D12 (dostęp: 28 XII 2015); AL, 1.6. Papirus Jumilhac, XIII,15-XIV,21, w: J. L i p i ń s k a, M. M a r c i n i a k, Mitologia starożytnego Egiptu, Mitologie świata, Warszawa 1977, s. 165 (dalej: LM).

${ }_{14} \mathrm{P}$ h i 1 o s t r a t u s, Life of Apollonius of Tyana, 3.8-9, http://www.livius.org/ sources/content/philostratus-life-of-apollonius/ (dostęp: 31.12.2015).

15 Zwycięskie walki Ninurty z Górą, w: Mity sumeryjskie, tłum. K. S z a r z y ń s k a, Antologia literatury mezopotamskiej, Warszawa 2000, s. 151 (dalej: MS).

${ }_{16} \mathrm{Ph}$ i lo s t r a t u s, Life of Apollonius of Tyana, 3.7-9; AL, 2.4; P t o l e m y He p h a e s t i o n, New History, 190, http://www.tertullian.org/fathers/photius_copyright/photius_05bibliotheca.htm (dostęp: 29 XII 2015); Papirus 1115, w: Z. D r a p e 11 a, Od Lewiatana do Jormungandra, s. 139.

17 A e li a n, On the characteristics of animals with an english translation by A. F. Scholfield, Books VI-XI, 2.21, 6.21.

18 Nonnus of Panopolis, Dionysiaca, t. II: Books XVI-XXXV, 25.451-538.

19 A e $1 \mathrm{i}$ a n, On the characteristics of animals with an english translation by A. F. Scholfield, Books VI-XI, 6.21.

20 O w i d i u s z, Przemiany, tłum. B. K i c i ń s k i, Wrocław 1953, 333-358.

${ }^{21}$ Hy gi in us, Fabulae, tłum. M. G r a n t, 30, http://www.theoi.com/Text/ HyginusFabulael.html (dostęp: 27 X 2014) (dalej: HF). 
jednak, że był przyjemny, ponieważ miał służyć wabieniu ofiary²2) lub syk, którego dźwięk był na tyle przerażający, że zdarzały się osoby, które umarły ze strachu. ${ }^{23}$ Wbrew typowym dla naszej kultury skojarzeniom rzadko miały możliwość posłużenia się ogniem. Spośród europejskich smoków używała go jedynie Chimera i Tyfon, ${ }^{24}$ ale jest to umiejętność typowa dla egipskich bestii, które jednak nie stosowały jej na polowaniu, lecz w starciu z istotami wrogimi Słońcu i oświetlaniu mu drogi w Dat (Ankhaa-Pau, ${ }^{25}$ Anubis, smoki służące bogom). Jeszcze inne miały magiczne właściwości np. wzrok zamieniający w kamień $\left(\right.$ Meduza $\left.^{26}\right)$; broń np. błyski powodujące sen / paraliż ofiary $\left(\right.$ Huwawa $^{27}$ ) lub umiejętność posługiwania się magią (Anzu, smok z Papirusu 1115, Mehen, Tiamat ${ }^{28}$ ).

Będąc tak śmiercionośne, same zdawały się być uodpornione na ciosy. Chociaż część można było zgładzić za pomocą zwyczajnej broni - maczugi, miecza, strzał (najlepiej zatrutych), głazów lub rozgrzanego metalu ${ }^{29}$ - często konieczne było posłużenie się magią (Kolchidzki, smoki górskie, $\mathrm{Jam}^{30}$ ), a i to nie gwarantowało sku-

${ }^{22}$ A e $1 \mathrm{i}$ a n, On the characteristics of animals with an english translation by A. F. Scholfield, Books VI-XI, 2.21.

${ }^{23}$ A pollonios z Rodos, Argonautica, 4.122-144, http://www.gutenberg. org/files/830/830-h/830-h.htm\#link2H_4_0004 (dostęp: 28 XII 2015).

${ }^{24}$ H o m e r, Iliada, 6.148-151, http://www.gmzielonka.edu.pl/szkolna_bibl_cyfr/ebooki/Homer\%20-\%20Iliada.pdf (dostęp: 27 X 2014); AL, 1.6.

25 KA, s. 48; LM, s. 164.

26 AL, 2.4.

27 Gilgamesz i Huwawa, w: ES, s. 60-62.

28 Lugalbanda $z$ Unug, w: tamże, s. 42; Papirus 1115, w: Z. D r a p e 11 a, Od Lewiatana do Jormungandra, s. 139; KA, s. 81; J. B ro m s k i (oprac.), Enuma Eliš, czyli opowieść babilońska o powstaniu świata, Wrocław 1998, IV,71.

${ }^{29}$ Hyg i n u s, Astronomica, tłum. M. G r a n t, 2.6, http://www.theoi.com/ Text/HyginusAstronomica.html (dostęp: 22 II 2016) (dalej: HA); O w i d i u s z, Przemiany, 3.65-68; S i m o n ides, Fragments, 573; A p ollonios z Rodos, Argonautica, 4.1393-1449; HF, 178. The Kârnâmag î Ardashîr î Babagân, tłum. D.D.P. S a n j a n a, 8,1-11, http://www.avesta.org/mp/karname.htm (dostęp: 22 II 2016).

$30 \mathrm{O}$ w i d i u s z, Przemiany, 7.153-161; P h i l o s t r a t u s, Life of Apollonius of Tyana, 3.8-9. Spór Baala z Jamem, w: KTU, 1.2 iv. 
tecznego efektu. Niektóre smoki były bowiem nieśmiertelne ${ }^{31}$ lub też miały umiejętności - regenerację $e^{32}$ - lub wiedzę (o ziołach przywracających do życia $\left.{ }^{33}\right)$, by za takie uchodzić. Dodatkową przewagę stanowiła niekiedy wrodzona czujność (Ladon, Smok kolchidzki ${ }^{34}$ ) czy umiejętność zmiany wyglądu (Asag, pomocnicy Tiamat ${ }^{35}$ ). Najczęściej jednak najskuteczniejszą ochroną była inteligencja i czasem powiązana z nią umiejętność posługiwania się ludzką mową, umożliwiająca pokojowe współistnienie obu gatunków. Nie zawsze jednak, czy to z powodu smoka, ${ }^{36}$ czy ludzi było to możliwe. ${ }^{37}$

Niekiedy bowiem zgładzenie smoka nie było konieczne (Smok kolchidzki ${ }^{38}$ ) lub wręcz nie było wskazane $\left(\right.$ Huwawa $\left.^{39}\right)$, powodując zaciągnięcie nieczystości, zmazy, którą trzeba oczyścić, zadośćuczynić, odpokutować (Apollo, $\mathrm{Kadmos}^{40}$ ). Mimo to wielu podejmowało się tego zadania w celu zdobycia smoczego cielska, które miało magiczne właściwości lub piękny wygląd. Oprócz skór

31 Ladon (AL, 2.5.11.), jedna z głów Hydry (AL, 2.5.2), Smok kolchidzki (Apollonios z Rodos, Argonautica, II.1200-1215); Echidna (Hezjod, Teogonia, 303-304).

$32 \mathrm{AL}, 2.5$.

33 Nonnus of Panopol is, Dionysiaca, t. II: Books XVI-XXXV, 25.451-538.

34 HA, 2.6; A pollonios z Rodos, Argonautica, 2.402.

35 Zwycięskie walki Ninurty z Góra, w: MS, s. 147. Enuma Eliš, I,113-124, w: K. Ły c z k ow s k a, K. S z a r z y ń s k a, Mitologia Mezopotamii, Mitologie świata, Warszawa 1981, s. 201 (dalej: ŁS).

36 Znamienna jest tu historia Sfinksa, który, wykorzystując swoją inteligencję i przewagę nad ludźmi, zrzuca w przepaść tych, którzy nie odgadli zagadki; HF, 67.

37 Przykładem tego jest Huwawa, który nie pragnie śmierci bohatera, lecz próbuje go odstraszyć. W obliczu nieustępliwości Gilgamesza nawiązuje z nim rozmowę i zwiedziony obietnicami herosa oddaje mu broń, zostaje powalony i zgładzony przez jego towarzysza Enkidu; Gilgamesz i Huwawa, w: ES, s. 63-64.

$38 \mathrm{O}$ w i d i u s z, Przemiany, 7.153-161.

39 Gilgamesz i Huwawa, w: ES, s. 64.

40 K. E 1 i a n, Opowiastki rozmaite, 3.1, tłum. M. B o r o w s k a, w: t e n ż e, Opowiastki rozmaite. Listy wieśniaków, Warszawa 2005, s. 82. Zgodnie z jednymi mitami za zabicie smoka Kadmos sam został zmieniony w smoka; HF, 6. Niektórzy twierdzili, że odpracował swoją winę, służąc Aresowi przez 8 lat; AL, 3.4. 
przypominających szlachetne metale - srebro i złoto ${ }^{41}$ - niemal niezniszczalnych zębów, z których, w przypadku niektórych mitów, po posianiu wyrastali uzbrojeni mężczyźni ${ }^{42}$ (podobną właściwość mogła mieć także krew bestii, czego efektem był Pegaz, Chrysaor i Smok kolchidzki ${ }^{43}$ ), wartościowe były także serca i wątroby, których zjedzenie pozwalało człowiekowi zrozumieć mowę i myśli zwierząt. Najcenniejsze jednak były kamienie ogniste, znajdujące się w źrenicach oczu, oraz kwieciste, mieniące się wszystkimi kolorami tęczy, tkwiące w głowach smoków ${ }^{44}$ - które miały wiele tajemnych zastosowań, np. po oprawieniu w pierścień czyniły jego właściciela niewidzialnym. ${ }^{45}$ Niekiedy też martwe ciała zachowywały szczególne właściwości danego smoka - np. głowa Meduzy wciąż potrafiła zmieniać w kamień. ${ }^{46}$

\section{Smocze siedziby}

Gdzie zatem można je było spotkać? Oprócz potworów zamieszkujących zaświaty - czy to egipskie Dat, czy grecki Hades ${ }^{47}$ - oraz licznych bestii zamieszkujących morza, ${ }^{48}$ będące $\mathrm{z}$ reguły poza zasięgiem ludzi (przynajmniej do czasu), szczególnie chętnie zamiesz-

${ }^{41}$ Złote skrzydła gorgon (AL, 2.4), złota głowa Hydry (P t o le my He p h a e s t i o n, New History, 190), złote ciało smoka opisanego w Papirus 1115, w: Z. D r a p e 11 a, Od Lewiatana do Jormungandra, s. 139; złotołuskie, indyjskie smoki górskie (Philos trat u s, Life of Apollonius of Tyana, 3.8-9); srebrne, indyjskie smoki pogórskie (tamże, 3.7).

42 AL, 3.4.

43 Tamże, 2.4; A pollon ios z Rodos, Argonautica, 2.1206-1215. Chociaż inni mitografowie podają, że ten ostatni jest dzieckiem Tyfona i Echidny; HF, Wstęp.

$44 \mathrm{Ph}$ il o s t r a t u s, Life of Apollonius of Tyana, 3.7-9.

45 P l a t o n, The Republic, tłum. B. J ow e t t, 2, http://classics.mit.edu/Plato/ republic.3.ii.html (dostęp: 31 XII 2015).

46 Nonnus of Panopolis, Dionysiaca, t. II: Books XVI-XXXV, 25.80.

47 KA; D i o d or u s S i c ul u s, Library of History, tłum. C. H. Old fat he r, 4.25.1, http://www.theoi.com/Text/DiodorusSiculus5B.html (dostęp: 27 X 2014).

${ }^{48} \mathrm{O}$ p p i a n, Halieutica, tłum. A.W. M a i r, 5.20nn., http://penelope.uchicago.edu/Thayer/E/Roman/Texts/Oppian/home.html\#Halieutica (dostęp: 30 XII 
kiwały trzy obszary ziemi - Frygię, Etiopię i Indie ${ }^{49}$ (aczkolwiek nie tylko). Obierały sobie siedzibę w rejonach raczej niedostępnych czy nieprzyjaznych ludziom, jak bagna $\left(\mathrm{Hydra}^{50}\right)$, góry (Anzu i inni $\left.{ }^{51}\right)$, jaskinie (Smoczyca scytyjska, Lamia ${ }^{52}$ ), rzadziej stepy. ${ }^{53}$ Okolice gajów, lasów, ogrodów lub miast zamieszkują raczej na rozkaz bogów (Ladon, Smok kolchidzki, Ismenios ${ }^{54}$ ) lub przez wzgląd na ludzi (Kekrops, Erichtonios, Robaczek ${ }^{55}$ ).

\section{Pochodzenie smoków}

Skąd wzięły się smoki? Najbardziej naturalnym sposobem było zrodzenie ze związku dwóch potworów - taki był początek Gorgon, Cerbera, Smoka kolchidzkiego, Scylli, Hydry, Chmiery, Sfinksa i Ladona ${ }^{56}$ - lub też bogów z innymi istotami - Ismenios, Hedammu, Set, Anubis, Geb, Irta (i jego dzieci): ${ }^{57}$ a pośrednio także Erichtonios, który narodził się z ziemi skropionej nasieniem Hefajstosa. ${ }^{58}$ Podobny

2015); A e li a n, On the characteristics of animals with an english translation by A. F. Scholfield, Books VI-XI, 16.18 .

49 Tamże, 2.21; P h i 1 o s t r a t u s, Life of Apollonius of Tyana, 3.6.

$50 \mathrm{AL}, 2.5$.

$51 \quad$ Lugalbanda z Unug, w: ES, s. 39-40.47.

52 H e rod ot, Dzieje, 4.9.1, http://www.imperiumromanum.edu.pl/art/herodot\%20-\%20dzieje.pdf (dostęp: 27 X 2014); A nton inus Liberalis, Metamorphoses, tłum. F. C e 1 o r i a, London-New-York 2001, 8.

${ }_{53}$ The building of Ningirsu's temple, w: The Electronic Text Corpus of Sumerian Literature, University of Oxford 906 (dalej: ETCSL).

54 HA, 2.3; A pollonios z Rodos, Argonautica, 2.402; Owidius z, Przemiany, 3.33-58.

55 S t r a b o, Geography, 9.2, http://www.perseus.tufts.edu/hopper/text?do c=Perseus:text:1999.01.0239:book=13:chapter=1 (dostęp: 27 X 2014); AL, 3.14.6; The Kârnâmag î Ardashîr î Babagân, 6,1-8.4.

56 AL, 1.2.

57 Tamże, 3.4. M. P o p k o, Mitologia hetyckiej Anatolii, Mitologie świata, Warszawa 1980, s. 147; LM, s. 57, 144-145; W. M. Mü 11 e r, Egyptian, The Mythology of All Races XII, Boston 1918, s. 111 (dalej: Mü); P. W i 1 k i n s o n, N. P h i 1 i p, Mitologia, tłum. M. G r u d z i ń s k a, Warszawa 2008, s. 291; AN, s. 35-36.

58 AL, 3.14. 
początek miał Smok kolchidzki, z tą różnicą, że czynnikiem zapładniającym była krew Tyfona. ${ }^{59}$ Oba mity zdają się łączyć przedstawioną tradycję ze starszą, w której smoki rodziły się z żywiołów - ziemi (Kekrops, Tyfon, $\mathrm{Asag}^{60}$ ) lub wody $\left(\mathrm{Anzu}^{61}\right)$, a uściślając praoceanu Kematef, ${ }^{62}$ Nenet, Kuket, Huhet i Amonet. ${ }^{63}$

Niekiedy były one stworzone przez bogów - Zahak, pomocnicy Tiamat $^{64}$ - lub w wyniku ich interwencji zmieniali kształty z ludzkiego $\left(\operatorname{Kadmos}^{65}\right)$ lub boskiego (Harmonia, Dumuzi ${ }^{66}$ ) na smoczy. Niezwykle rzadko istniały bez początku, jeszcze przed stworzeniem świata (Tiamat, Aton ${ }^{67}$ ).

\section{Życie pogrobowe smoków}

Podobną zagadkę stanowi kwestia życia pośmiertnego. Oprócz kilku smoków wynagrodzonych za służbę przez umieszczenie na nocnym niebie - Ladon, ${ }^{68}$ smoki Demeter ${ }^{69}-\mathrm{i}$ kilku innych prze-

59 A pollonios z Rodos, Argonautica, 2.1206-1215; HF, Wstęp.

${ }^{60}$ AL, 3.14; He z j o d, Teogonia, 820-822. Zwycięskie walki Ninurty z Górą, w: MS, s. 142-143.

${ }^{61}$ Mit o ptaku Anzu, I, tłum. M. S t o la r c z y k, M. K a p e $\nmid$ u ś, w: Mity akadyjskie, tłum. O. D r e w n ow s k a - R y m a r z, K. G aw li k ow s k a i in., Antologia literatury mezopotamskiej, Warszawa 2000, s. 63.

62 AN, s. 35-36.

63 Tamże, s. 36.

${ }^{64}$ Zamyad Yasht: w: Khorda Avesta, Yashts, Sacred Books of the East, tłum. J. D a r m e s t e t e r, VII, 37, http://www.avesta.org/ka/yt19sbe.htm (dostęp: 22 II 2016); Enuma Eliš, I,113-124, w: ŁS, s. 201.

$65 \mathrm{HF}, 6$.

66 Tamże; ŁS, s. 135.

${ }^{67}$ Enuma Eliš, I,1-5, w: ŁS; . Z. D r a p e 11 a, Od Lewiatana do Jormungandra, s. 130.

${ }^{68} \mathrm{HA}, 2.3$. Inny mit podaje że jest to inny smok - Gigantios - który w czasie wojny bogów z gigantami został rzucony niczym oszczep w stronę Ateny, ta jednak uniknęła ciosu, złapała smoka i rzuciła nim w gwiazdy, tworząc nowy gwiazdozbiór; HA, 2.3.

${ }^{69}$ Choć czasem był to wyraz podziwu dla starcia herosa z tą bestią (HA, 2.14) lub powód do wstydu dla mordercy boskiego sługi (tamże). 
niesionych do piekieł - Chimera, Hydra, Gorgony ${ }^{70}$ większość po prostu ginie. Nawet mitologia egipska, znacznie bardziej niż grecka czy rzymska zainteresowana życiem po życiu, omija tę kwestię. Tylko w przypadku jednego smoka - Seta - istnieje jedna krótka wzmianka sugerująca, że po śmierci ciała, jego dusza zostaje uwięziona na zachodzie. $^{71}$ Argumentem na potwierdzenie szerszego istnienia tej wersji są przedstawienia gwiazdozbiorów, spośród których jeden przedstawia pilnowaną przez strażników, skutą nogę Seta. ${ }^{72}$

\section{Funkcjonowanie motywu smoka}

\section{Starcie bohatera ze smokiem}

Pierwszym motywem przychodzącym na myśl ludziom z naszego kręgu kulturowego w związku ze smokiem jest zabicie potwora gustującego w dziewicach przez bohatera, który, z wdzięczności za uwolnienie ludzi od tej plagi, zdobywa rękę królewny i połowę królestwa. Ten najbardziej rozpowszechniony motyw kultury europejskiej - wspomnijmy chociażby legendy o św. Jerzym, Szewczyku Dratewce itd. - ma swoje korzenie w mitologii grecko-rzymskiej. Jednak nie zawsze pojawiają się wszystkie typowe dlań elementy, tzn. smok siejący postrach wśród ludzi i stad, składanie ofiar z ludzi, zdobycie żony i królestwa.

W wielu mitach smok postrzegany jest jako zagrożenie dla ludności i stad; ${ }^{73} \mathrm{z}$ którym większość ludzi nie jest w stanie sobie poradzić, dlatego, chcąc ograniczyć straty, za radą wyroczni, składają im ofiary z ludzi. Najczęściej strawą dla bestii zostają młodzi ludzie wskazani losem, zarówno kobiety jak i mężczyźni, chociaż w szczególnych

${ }^{70}$ Publius Wergilius Maro, Eneida, tłum. T. Karyłowski, 6.287, http://biblioteka.kijowski.pl/antyk\%20rzymski/publiusz\%20wergiliusz $\% 20$ maro_eneida.pdf (dostęp: 22 X 2016).

${ }^{71}$ Księga Umartych, w: Mü, s. 72.

72 Mü, s. 59, 109-110.

73 A e 1 i a n, On the characteristics of animals with an English translation by A. F. Scholfield, Books VI-XI,2.21; HA, 2.14. 
przypadkach, gdy smok postrzegany jest jako kara zesłana przez bogów, konieczne jest złożenie konkretnej osoby - córki tego, który wywołał gniew bóstw. Wtedy też pojawia się bohater, który - zakochawszy się (od pierwszego wejrzenia) w przyszłej ofierze - ratuje ją od śmierci, zabijając smoka (czasem nawet za cenę własnego życia).

Najlepszym przykładem realizacji tego schematu jest historia Andromedy, złożonej w ofierze bezimiennemu smokowi, zesłanemu przez Posejdona, uratowanej przez Perseusza, przyszłego męża. ${ }^{74}$ Podobna opowieść dotyczy Alkyoneusa, ocalonego przez Eurybarosa, który zakochawszy się w nim, pozwolił złożyć się zamiast niego w darze Lamii, by zrzucić ją w przepaść. ${ }^{75}$ Nieco odbiega od schematu mit o Smoku tespijskim nawiedzającym Tespie, miasto w Grecji. Wskazanego przez los Kleostratesa uratował jego kochanek, Menestratos, który poświęcił własne życie, ale zgładził stwora. ${ }^{76}$ Także Thraeton staje przeciwko „Królowi o smoczym ciele” Azi Dahace, by wyzwolić dwie żony władcy - Sahanhawacz i Arenawacz - i zwycięża dzięki przychylności bogini Anahity. ${ }^{77}$ Wątek miłosny pojawia się nie tylko w przypadku Heraklesa (choć w niektórych wersjach zakończenia mitu heros lub jego towarzysz dostaje księżniczkę za żonę ${ }^{78}$ ), który jako rekompensatę swoich wysiłków żąda klaczy. ${ }^{79}$ Widać w ten sposób, że choć często zdobycie żony (lub kochanka) jest motywem działania bohaterów, czasem jest ono jedynie skutkiem ich czynów (tak jak w przypadku Heraklesa, Jazona, który przybywając po złote runo wyjechał nie tylko ze skarbem ale i Medeą,

74 HF, 64.

75 Antoninus Liberalis, Metamorphoses 8.

76 P a u zan i a z, Wędrówka po Helladzie, 26.7-8, http://biblioteka.kijowski. pl/antyk\%20grecki/\%20pauzaniasz\%20\%20w\%E4\%99dr\%E3\%B3wka\%20po\%20 helladzie\%20ks.1-10.pdf (dostęp: 27 X 2014).

77 Aban Yasht, w: Khorda Avesta, Sacred Books of the East, tłum. J. D a r m e s t e t e r, VII-IX, http://www.avesta.org/ka/yt5sbe.htm (dostęp: 27 X 2014).

78 D i o d or us S i culu s, Library of History, 4.42.6; HF, 89.

79 AL, 2.5. 
wspomagającą go w tych wysiłkach; ${ }^{80}$ oraz Edypa) lub ustępuje na rzecz innych, przeważnie materialnych, korzyści.

Najczęstszym z nich jest zdobycie królestwa (lub miasta-państwa w przypadku kultury greckiej). Z taką sytuacją mamy do czynienia w przypadku Edypa, który w zamian za pokonanie Sfinksa, będącego plagą zesłaną przez Herę na Teby, otrzymuje to miasto wraz z Jokastą, wdową po poprzednim królu Lajosie. ${ }^{81}$ Także Kychreus dopiero po zgładzeniu Smoka kychreidzkiego przejmuje władzę nad nawiedzaną przez niego Salaminą. ${ }^{82}$ Odwróconą kolejność widzimy jedynie w micie o Smokach rodyjskich. W tym przypadku mieszkańcy wyspy nękani przez bestię, za radą wyroczni, ofiarowują Phorbosowi ziemię, aby skłonić go do pozbycia się tej plagi, co też uczynił ${ }^{83}$ (chociaż inni twierdzą, że pogromca trafił na wyspę przypadkiem przyniesiony przez sztorm ${ }^{84}$ ).

Spośród innych motywów skłaniających bohatera do podjęcia wyzwania zauważyć należy zemstę za śmierć lub wyrządzoną krzywdę. W przypadku Kadmosa jest to chęć pomszczenia zamordowanych przez smoka Ismeniosa towarzyszy. ${ }^{85}$ Adrastus i armia Siedmiu Przeciw Tebom z kolei odpłacili bestii za zabicie Opheleta. ${ }^{86}$ Gigant Damascen zwrócił się przeciwko smokowi Maioniosowi, gdy Moria zwróciła się do Niego z prośbą o pomszczenie jej brata Tylosa. ${ }^{87}$ Tymczasem Apollo zabił Pytona, zgodnie z jedną z wersji mitu, ponieważ prześladował matkę boga - Latonę, próbując zapobiec narodzinom swojego przyszłego mordercy. ${ }^{88}$ Zaś Gorszasp odpłacał smokom za

80 O widius z, Przemiany, 7.160-162; D i od or u s S iculus, Library of History, 4.83.3.

${ }^{81} \mathrm{AL}, 3.5 ; \mathrm{HF}, 67$; P a u z a n i a s z, Wędrówka po Helladzie 9.26.2; D i o d o r u s S i c u 1 u s, Library of History, 4.64.4.

82 Tamże, 4.72.4.

83 Tamże, 5.58.4.

84 HA, 2.14

85 O w i d i u s z, Przemiany, 3.33-58.

${ }^{86}$ AL, 3.6.4; HF, 74.

${ }^{87}$ Nonnus of Panopol is, Dionysiaca, t. II: Books XVI-XXXV, 25.451-538.

$88 \mathrm{HF}, 140$. 
krzywdę wyrządzoną mu przez jednego z nich, tzn. doprowadzenie go do grzechu uniemożliwiającego mu po śmierci przekroczenie bram raju - zalanie ognia zawartością kotła. ${ }^{89}$

Stosunkowo najrzadszym powodem jest wypełnianie powierzonego przez kogoś innego zadania. Najbardziej znanym przypadkiem jest historia Heraklesa, który, pokutując za zamordowanie żony i dzieci, musiał wykonać dwanaście wyznaczonych mu przez Eurysteusza, prac. Drugą z nich jest pokonanie Hydry lernejskiej..$^{90}$ Podobna sytuacja dotyczy Tiszpaka, pogromcy żmii Baszmu ${ }^{91}$ i smoka Labbu. Chociaż historia starcia ich obu zachowała się fragmentarycznie, najprawdopodobniej bóg Sin polecił Tiszpakowi zabić stwora, niszczącego wszystko na swojej drodze. ${ }^{92} \mathrm{Na}$ wezwanie do pokonania smoka odpowiadają w innych mitach także Ninurta, mierząc się z Anzu, ${ }^{93}$ oraz Inara, która stawiła czoło Illujance - przeciwnikowi jej ojca. ${ }^{94}$

\section{Związki z bogami}

Wielkość, siła, niezwykłość smoków skłaniały niekiedy do przypisywania im boskiej roli lub uznania jakiegoś rodzaju pokrewieństwa / powinowactwa z istotami przewyższającymi człowieka. Doprowadziło to do oddawania im boskiej czci, co zagrażało kultom innych nie-smoczych bóstw, a w konsekwencji do „starcia” i powstania opowieści o rządnym władzy smoku, który został pokonany przez,

89 Jasna, w: The Zend-Avesta, Sacred Books of the East, thum. J. D a r m e s t e t e r, 9,11, http://www.avesta.org/yasna/yasna.htm (dostęp: 27 X 2014). Z punktu widzenia Zaratusztrian był to grzech, ponieważ ogień uznawano za święty, był bowiem cząstką Ahura Mazdy przenikającym całe stworzenie.

90 AL, 2.5.

91 ŁS, s. 216-217.

92 Smok Labbu, tłum. M. K a p eł u ś, w: MA, s. 77-78.

93 Mit o ptaku Anzu, I, w: MA, s. 64-65.

94 Mit o Illujance, pierwsza strona tabliczki, w: M. P o p k o, Mitologia hetyckiej Anatolii, s. 63-64. 
dominującego w tym regionie, boga lub prezentowanie tych istot jako służących bogom, pełniących jedynie ich wolę.

\section{Bóg-smok}

Bogowie przyjmujący lub mający smocze kształty to typowy motyw mitologii egipskiej ${ }^{95} \mathrm{i}$ bliskowschodniej, praktycznie nie pojawiający się w kulturze grecko-rzymskiej - wyjątkiem jest smok Ismenios, który uważany był za potomka boga Aresa/Marsa, ale nie za boga. ${ }^{96}$ Te smocze bóstwa miały pewne wspólne cechy, tj. przyporządkowanie do pewnych obszarów, działań. Jednym z nich są zaświaty, należą do nich Ozyrys - główne bóstwo śmierci w Egipcie $^{97}$ - bóg zmarłych Anubis, patron balsamowania i strażnik grobów, ${ }^{98}$ oraz Dumuzi, który przeszedł ewolucję od bóstwa pasterzy do jednego z siedmiu wielkich bóstw w jednym z siedmiu okręgów kur. ${ }^{99}$

Inną kategorię stanowią bóstwa powiązane z ziemią jak Renenutet - wężowa bogini żniw i płodów ziemi - Geb, będący personifikacją ziemi, niekiedy przedstawiany jako człowiek z wężową głową. ${ }^{100}$ Bóstwa powiązane $\mathrm{z}$ wodą z kolei przyczyniają się do powstania świata. Należą do nich Tiamat, z której ciała utworzono świat, ${ }^{101}$ oraz Nenet, personifikacja prawód i zalążków granic wszechświata: górnego i dolnego nieba oraz jej towarzyszki: Kuket (uosobienie ciemności),

95 To powiązanie bóstw i smoków widoczne jest już w piśmiennictwie egipskim - hieroglif oznaczający boginie ma kształt węża. Prawdopodobnie wynika to z faktu, że wąż był wykorzystywany także w innym hieroglifie używanym np. do zapisywania słowa dżet - „wieczność”; zob. AN, s. 103.

96 AL, 3.4

97 A. C o t te re 11, Słownik mitów świata, tłum. W. C e r a n, M. D ą b r o w ska, R. Folt y n, P. K r u p c z y ń s k i, J. S k ow roń s k i, Katowice 1996, s. 51; P. Wilkinson, N. Ph il i p, Mitologia, s. 343.

98 Tamie, s. 343.

99 Zejście Inany do świata podziemnego, w: MS, s. 98-100. Śmierć króla Urnaтmu z Uri, w: ES, s. 118-119.

${ }^{100}$ K. M i c h ało w s k i, Nie tylko piramidy... Sztuka dawnego Egiptu, Warszawa 1974, s. 97; P. W i 1 k in s o n, N. P h 11 i p, Mitologia, s. 291; AN, s. 53.

${ }^{101}$ Enuma Eliš, IV, w: ŁS, s. 129-140. 
Huhet (ucieleśnienie nieskończoności czasowej i przestrzennej) oraz Amonet (symbol niewidzialności, ukrytości), które wraz ze swoimi męskimi, żabimi odpowiednikami utworzyły kosmiczne jajo, będące początkiem całego świata. ${ }^{102}$ To powiązanie ze stworzeniem widoczne jest także w przypadku innych smoków - kosmicznego węża Kematefa (uznanego za hipostazę Amona), który zrodził innego węża, Irtę (tj. „Tego-Który-Uczynił-Ziemię”), stworzyciela świata. ${ }^{103}$ Także inny bóg rozpoczynający dzieło kreacji - Atum - powiązany był z motywem węża-smoka, ponieważ wierzono, że istniał w tej formie przed stworzeniem świata pływając w praoceanie. ${ }^{104}$

Ostatnią kategorią smoków-bogów są bóstwa opiekuńcze, chroniące albo konkretną osobę albo obszar. Zaliczyć do nich należy Robaczka - bóstwo czczone przez mieszkańców Stolicy, które obalił/ zabił Ardaszir jako konkurencję dla wyznawanego przez siebie zaratusztrianizmu. ${ }^{105}$ Patronką faraona i państwa egipskiego jest bogini Wadżet, czczona pod postacią kobry, powiązana z plującym ogniem wężem - Ureuszem - znajdującym się m.in. na koronach faraonów. ${ }^{106}$ Należy do nich także, wspomniany w poprzednim rozdziale Set pełniący początkowo rolę opiekuna Górnego Egiptu, a tym samym patrona faraona na równi $\mathrm{z}$ Horusem. $Z$ czasem rola ta zanikła na rzecz patronowania żołnierzom, Azjatom oraz bycia bogiem nieba, a zwłaszcza grzmotów. ${ }^{107}$

Szczególną grupę stanowią węże czasu, nie uznawane za bóstwa lecz będące personifikacją czasu: „Ten-Który-Zabiera-Godziny”,

\footnotetext{
102 AN, s. 36.

103 Tamie, s. 35-36.

${ }^{104}$ Tamże, s. 49-53.

105 The Kârnâmag î Ardashîr î Babagân, 6,1-8,11.

${ }^{106}$ LM, s. 206-207.
}

${ }^{107}$ Chociaż skojarzenie Seta z bogiem grzmotów i, pośrednio, nieba jest dziełem ludów zamieszkujących na północ od Egiptu (ze względu na rzadkość burz w samym Egipcie); nie jest obce także Egipcjanom, którzy powiązali go albo z chmurami burzowymi, albo z burzą, z tym że to ostatnie zjawisko pojmowane było jako manifestacja walki Seta z Horusem, w czasie, której bratanek rani wuja włócznią-piorunem, zaś ten grzmi z bólu; zob. Mü, s. 103-104, 108, 155. 
niesiony przez bóstwa na rękach „Ten-Który-Otacza-Świat”108 oraz Ka-em-ankh-neteru „Dusza-Tego-Który-Pozwala-Żyć-Bogom” lub krócej Ankh-neteru „Życie-Bogów” - Wielki wąż, do którego słoneczna barka codziennie ,wchodzi w jego ogon i wychodzi z jego ust, i rodzi się w postaci Chepry ${ }^{109 "}$ ".

Wiele pomniejszych bóstw, także miało wężową/smoczą postać, jednak nie zawsze przetrwała pamięć o pełnionych przez nie zadaniach, funkcjach a jedynie barwne opisy lub obrazy form, które przybierały. ${ }^{110}$

\section{Walka z bogami}

Nie zawsze jednak współżycie smoków z bogami przebiegało tak pokojowo, nieraz dochodziło do starć, których przyczyną była walka o władzę. Dość powszechnie przyjmuje się, że w konflikt z bestiami wchodziły bóstwa solarne, ale ich domeną mogły być także zjawiska atmosferyczne, zwłaszcza pioruny, oraz miłość/płodność i wojna.

Najczęściej wymienianym starciem bóstwa solarnego ze smokiem jest konflikt Tiamat z Mardukiem, w który smok, a właściwe smoczyca, zostaje wciągnięta przez innych bogów z powodu buntu młodszej generacji przeciwko pierwszej. Apsu, jej partner i protoplasta wszystkich bogów, zostaje zabity przez Ea, który, wiedząc o zamiarze swojego pradziadka (tj. zgładzeniu wszystkich zbuntowanych bóstw), uprzedza jego atak. Wywołuje to gniew Tiamat i choć nie popierała

108 AN, s. 151-152.

109 Tamże, s. 154; por. KA, s. 138-141.

110 Taki los stał się udziałem bóstw egipskich: Nehebkau „Ten-Który-Jednoczy-Cechy”, Sa-ta „Syn-Ziemi”, Harsomtusa z Dendery czy Neferhotepa z Hu (AN, s. 37) oraz bliskowschodnich: Mutu (Sen księcia Kummy, tłum. K. G a w l i k o w s k a, w: MA, s. 121), Nin-tu (Tabliczka DD, 1-14, w: The devils and evil spirits of Babylonia, s. 146-149), bezimienna wybranka Ereszkigal, (Tabliczka DD, 26-41, w: tamże, s. 150-151), Sassu-urinnu (jedna z form Ea) (Tabliczka DD, 15-25, w: tamże, s. 148-149), zły bóg, jeden z siedmiu demonów wysłanników Anu (Tabliczka szesnasta, 1-54, w: tamże, t. I: Evil Spirits, tłum. R. C a m p be 11 T ho m p s o n, Luzac's Semitic Text and Translation Series XIV, London 1903, s. 88-93. 
działań męża, mających na celu uśmierzenie buntu, po jego śmierci ponownie wychodzi za mąż i wypowiada wojnę tym, którzy się do niej przyczynili. W wyniku starcia z synem Ea - bogiem Słońca, ale także zaklęć i wróżb, Mardukiem ${ }^{111}$ - ginie a wraz z nią jej sojusznicy, wśród których także były stworzone przez nią smoki. ${ }^{112}$

To starcie boga Słońca ze smokiem i jego armią odnaleźć możemy także w mitologii egipskiej, zgodnie z którą każdej nocy na orszak Ra czyhał wąż Apep, zwany też Apopisem lub Nehaherem, by zaatakować w momencie największej kulminacji dobra, a więc w godzinie siódmej - gdy Słońce się zregenerowało, łącząc swoją duszę i kształt - oraz dwunastej - gdy próbuje się ono ponownie „narodzić” na nieboskłonie. ${ }^{113}$ Codziennie jednak przegrywa starcie, zostaje skrępowany i pocięty na kawałki. ${ }^{114}$

Także inny aspekt boga Słońca - Horus, ${ }^{115}$ toczy spór ze smokiem - Setem, który zamordował jego ojca (a swojego brata), by przejąć władzę nad Górnym i Dolnym Egiptem. Historia starcia obu tych postaci jest niezwykle burzliwa i skomplikowana, ponieważ poszczególne mity podają różne epizody tej opowieści, będące nieraz w jawnej sprzeczności. Jednak wart zauważenia jest fakt, że walka nie ogranicza się jedynie do fizycznych starć (jak w przypadku większości mitów greckich - wyjątkiem jest tu historia Edypa), ale przybiera często formę zawodów, mających sprawdzić fizyczną wytrzymałość, siłę, łączących się z procesem sądowym toczonym przed innymi bóstwami. Racja ostatecznie zostanie przyznana Horusowi, wygrywającemu jednak za pomocą sprytu i oszustwa, a nie bezmyślnej siły. ${ }^{116}$ Dopiero potem doszło do utożsamieniu Seta z Nehaherem, ${ }^{117}$

111 ŁS, s. 317.

112 Enuma Elǐ̌s, I,1 - IV, w: ŁS, s. 146.

113 AN, s. 154. Trochę inaczej przebieg starcia przedstawia Księga Bram, podając, że Apopis atakuje w trzeciej i dziesiątej godzinie nocy.

114 KA, s. 71.

115 AN, s. 129; Mü, s. 27-28.

116 Papirus Chester Beatty, w: LM, s. 120-140; Stella Szabaki, w: tamże, s. 114 -116; Papirus Sallier, IV, w: tamże, s. 192.

117 Mü, s. 107; AN, s. 307. 
a w konsekwencji powstania mitów przedstawiających jego starcie z Ra i Horusem (postrzeganym wtedy jako syn tego solarnego bóstwa, a nie Ozyrysa). ${ }^{118}$

Grecy utożsamili postać Seta z ich rodzimym smokiem - Tyfonem, który rządny władzy nad światem atakuje olimpijskich bogów. Większość z nich ucieka, jedynie Zeus, bóg nieba, ${ }^{119}$ przeciwstawia się temu żywemu chaosowi. ${ }^{120}$ Przebieg walki był różny, w zależności od wersji mitu, choć Tyfon wygrywa bitwę - pozbawiając władcę wszystkich bogów nerwów i pioruna - ostateczne zwycięstwo należy do syna Kronosa. ${ }^{121}$ Intrygujące, że mit ten, przynajmniej w niektórych wersjach, jest uderzająco podobny do hetyckich opowieści o walce boga Burzy z Illujanką (tzn. Wężem, od hetyckiego illujanka - „wąż”). Tak jak w przypadku poprzedniej historii, władające piorunami bóstwo traci części swojego ciała, lecz, w przeciwieństwie do swojego greckiego odpowiednika, nie nerwy, a serce i oczy. W odzyskaniu ich także potrzebuje pomocy osoby trzeciej - w mitologii Hellenów był to Hermes i Egipan - w hetyckiej syn spłodzony (tylko w tym celu) z córką człowieka Biedaka, który, stając się zięciem potwora, odzyskuje utracone organy i zwraca je ojcu, podpisując tym samym wyrok śmierci na siebie i swoją rodzinę. ${ }^{122}$ Inny przebieg walki podaje opowieść z drugiej strony tabliczki (także przetworzona przez Greków $\left.{ }^{123}\right)$. Zgodnie z nią po wygraniu bitwy z bogiem Burzy, Illujanka z synami udaje się do jego córki i przejadłszy się, nie mogą ponow-

118 Mit o uskrzydlonym dysku stonecznym, XII, 2 - XVI,3. w: E.A. W a 11 is $\mathrm{B}$ u d g e, Legends of the Gods. The Egyptian Texts, edited with Translations, London 1912, s. 56-95; por. LM, s. 104-105.

119 A. C o t t e r e 11, Stownik mitów świata, s. 51; P. W i 1 k i n s o n, N. P h i 1 i p, Mitologia, s. 219-220.

${ }^{120}$ Por. J.-P. V e r n a n t, Mity greckie, czyli świat, bogowie, ludzie, tłum. J. Ł u k a s i e w i c z, Wrocław 2002, s. 34.

${ }^{121}$ AL, 1.39-44.

${ }^{122}$ Mit o Illujance, druga strona tabliczki, w: M. P o p k o, Mitologia hetyckiej Anatolii, s. 64-67.

${ }^{123} \mathrm{Z}$ tym, że przedstawia Tyfona jako walenia, a nie smoka; por. J.-P. V e r $\mathrm{n}$ a $\mathrm{nt}$, Mity greckie, czyli świat, bogowie, ludzie, s. 37. 
nie wpełznąć do domu. Moment słabości wykorzystuje człowiek Hupasija, który związał ich, by bogowie mogli ich następnie zabić. ${ }^{124}$

Także kanaanejski bóg deszczu, burzy, błyskawicy i płodności Baal $^{125}$ popada $\mathrm{w}$ konflikt $\mathrm{z}$ Jamem. U jego źródeł leży postępowanie pierwszego z nich, który znieważył najwyższe bóstwo Ela i próbował go sobie podporządkować. W ramach zemsty upokorzony ojciec bogów i ludzi usynawia Jama, oferuje mu wybudowanie pałacu, czyniąc syna Dagana jego niewolnikiem. W obliczu tej deklaracji Nahar wysyła posłów do rady bogów by wydano mu jego sługę. Doprowadza to Baala do takiej wściekłości, że atakuje posłańców (ale ich nie zabija dzięki interwencji Anat) i grozi Jamowi śmiercią. Po uzbrojeniu się w magiczną broń wykonaną przez Koszara niemal wprowadza swoje groźby w życie - przed zadaniem ostatecznego ciosu powstrzymuje go Asztarte. Jednak Jam zostaje zniewolony, a jego władza ograniczona do poprzedniego obszaru - oceanów.

Trzecią kategorią bóstw, wchodzącą w konflikt ze smokami, są bogowie miłości/płodności i wojny. Należą do nich pogromczyni wspomnianego wcześniej Jama ${ }^{126}$ - Anat ${ }^{127}$ oraz Isztar, ${ }^{128}$ chociaż opowieść o jej starciu z Hedammu nie zachowała się w całości. Potwór ten, nasłany został przez Kumarabiego, który, chcąc przejąć władzę nad światem, spłodził go z córką Morza, Szertapszuruhi. Rosnąc w zastraszającym tempie, potwór niszczy wszystko na swojej drodze. Isztar, widząc go, postanawia, za pomocą swoich wdzięków, wywabić go z morza, będącego najprawdopodobniej źródłem jego siły. Pozostaje zagadką, jak kończy się ta opowieść, ze względu na zbyt duże zniszczenie dalszych fragmentów tabliczki. ${ }^{129}$

${ }^{124}$ Mit o Illujance, pierwsza strona tabliczki, w: M. P o p k o, Mitologia hetyckiej Anatolii, s. 63-64.

125 A. C o t t e r e 11, Stownik mitów świata, s. 28-29.

${ }^{126}$ KTU, 1.1-1.2.

${ }^{127}$ P. W i 1 k i n s o n, N. P h i 1 i p, Mitologia, s. 330.

${ }_{128}$ Tamie, s. 315.

${ }^{129}$ M. P o p k o, Mitologia hetyckiej Anatolii, s. 147-152. 
Ze smokami mierzył się także akadyjski bóg huraganu, wojny i polowania ${ }^{130}$ - Ninurta, który wystąpił przeciwko Anzu, gdy ukradł on należące do Enlila Tablice Przeznaczeń, doprowadzając do nastania chaosu w świecie. Mimo przewagi przeciwnika, dzięki radom Ea, zdołał pokonać żądnego władzy ptaka - smoka i jego sojuszników. ${ }^{131}$ Oprócz nich Ninurta pokonał także Asaga, roszczącego sobie prawa do czynów właściwych bogom i podporządkowującego sobie ich w każdym zdobytym mieście, wraz z jego sprzymierzeńcami, wśród których ponownie pojawia się ptak Anzu. ${ }^{132}$

Wyjątkowym mitem jest opowieść o starciu boga wody, mądrości, magii i rzemiosła Enkiego ${ }^{133}$ z Kurem, ze względu na niezwykłość przyczyny konfliktu, którym nie jest, jak w poprzednich przypadkach, chęć przejęcia władzy, lecz porwanie przez smoka bogini Ereszkigal (którą prawdopodobnie chciał poślubić). Mit jednak się nie zachował, jego ślady odnaleźć możemy jedynie w cyklu opowiadań o Gilgameszu, co utrudnia odtworzenie tej historii (a zwłaszcza jej końca). ${ }^{134}$

Smoki służące bogom

Smoki uważano także za wypełniające wolę bożą. Najczęściej, ze względu na przypisywane im umiejętności, pełniły rolę strażników świętych miejsc lub skarbów. Ten typowy dla kultury europejskiej motyw strzeżenia przez smoka złota odnaleźć możemy w dwóch

130 ŁS, s. 319.

131 Mit o ptaku Anzu, I, w: MA, s. 63-73.

${ }^{132}$ Zwycięskie walki Ninurty z Góra, w: MS, s. 142-166. Kramer widział w tym opowiadaniu ślady mitu o pokonaniu Kur przez Ninurtę, który niszczy go w walce, powodując jednak katastrofę, ponieważ nic nie utrzymywało oceanu wód pierwotnych. S.N. K r a m e r, Sumerian Mythology - A Study of Spiritual and Literary Achievement in the Third Millennium B.C., Philadelphia 1961, s. 80-82.

133 ŁS, s. 314.

${ }^{134}$ Gligamesz, II, cyt. za: Gilgamesz. Epos babiloński i asyryjski ze szczątków odczytany i uzupetniony także pieśniami szumerskimi przez Roberta Stillera, tłum. R. S t i 11 e r, Warszawa 1967, s. 21. 
greckich mitach, ${ }^{135}$ dotyczących pilnującego złotych jabłek Hery Ladona, który zgodnie z większością mitów ginie z rąk Heraklesa wypełniającego jedną z wyznaczonych mu prac, ${ }^{136}$ oraz strzegącego złotego runa Smoka kolchidzkiego, pokonanego (ale nie zabitego) przez czary Medei. ${ }^{137}$

Tymczasem w kulturze egipskiej tymi cennymi skarbami było nie złoto, lecz zwłoki boga Słońca. ${ }^{138}$ Spośród takich strażników wymienić należy Ash-hrau tzn. „O-Wielu-Twarzach”, pilnującego całego ciała martwego boga Afu (Chepri) w ciągu szóstej godziny nocy. ${ }^{139}$ Niekiedy zastępowany jest przez węże plujące ogniem, które strzegą jednak jeszcze rozczłonkowanego ciała Re. ${ }^{140}$ Także wąż Chemet-em-bia strzeże soków cielesnych Ozyrysa. ${ }^{141} \mathrm{~W}$ stosunku do odrodzonego Ozyrysa/Re, funkcję tę pełni Mehen „Ten-Który-Otacza”, osłaniając swym cielskiem bóstwo przed zakusami jego wrogów. ${ }^{142}$ Podobną misję - ochrony przed przeciwnikami Słońca zwłaszcza Apopisem - pełni też wspomniany wcześniej Set, ${ }^{143}$ w późniejszym czasie utożsamiony z Wielkim Magiem - Heką. ${ }^{144}$ Jedynie Ankh-aru-tchefau-ankh-aru i Ankh-ta nie pilnują boga Słońca, lecz

${ }^{135} \mathrm{Philostratus}$ the Elder, Imagines, thum. A. Fa i rban k s, London-New York 1931, 2.17.6.

136 AL, 2.5.

${ }^{137}$ O w i d i u s z, Przemiany, 7.149-163.

${ }^{138}$ Należy pamiętać, że mitologia egipska nigdy nie była spójna, jednak kapłani dokładali starań, by łączyć różne tradycje. Dlatego też istnieją aż cztery różne formy Wielkiego Boga - Słońca, Ozyrys (władca świata umarłych / Słońce w nocy), Re (władca świata żywych / Słońce w południe), Chepry lub Horus (Słońce poranne) i Atum (Słońce nocne / wieczorne); zob. AN, s. 129; Mü, s. 27-28.

139 AN, s. 141; KA, s. 56-58.

140 AN, s. 141; KA, s. 62.

${ }_{141}$ Papirus Jumilhac, I,4-II,20, w: LM, s. 162-163.

142 KA, s. 73.

143 Harris Magic Papyrus, w: Mü, s. 107; Księga Umartych, w: J. B. P r i t c h a r d (red.), Ancient Near Eastern Texts: Relating to the Old Testament, Princenton-New Jersey 1969, s. 38 (dalej: ANET).

${ }^{144}$ AN, s. 144. 
odpowiednio boga Afu-asara ${ }^{145}$ oraz pozostałych węży zamieszkujących Amduat. ${ }^{146}$

Bóg Słońca posiadał zresztą znacznie więcej smoczych sojuszników mających wspomóc go w ostatecznej walce z zagrażającymi mu siłami i unicestwić jego wrogów. Należą do nich m.in. Am-khu („Który-Połyka-Kształty”), ,Ten-Który-Spala-Miliony”, Uamemti; ${ }^{147}$ Tekait, Khut-tuat, Tertneshen; Ap-shet, Ankhet, Shen-ten-amm; Aat-aru, Nebt-uauau, Nebt-rekeh; Senmekhef, Set-heh, wąż niosący Afu-tema. ${ }^{148}$ Także Ta-thenen, Tem, Chepri; Szu, Seb, Asar; Heru, Apu i Atepiu rozdzierają na strzępy zmarłych i palą wrogów boga Chepri, strzegąc w ten sposób boskiego Ciała. ${ }^{149}$

To powiązanie z karaniem odnosiło się także do ludzi - grzeszników, których dusze unicestwiały m.in. dwa potwory „Ten-Który-Kroczy” oraz „Spiżowy-Z-Ziemi”, pilnowane przez strażników, by nie obróciły się przeciwko sprawiedliwym. ${ }^{150}$ Najsłynniejszym jednak monstrum $z$ Dat ${ }^{151}$ zaangażowanym w takie działania jest Am-mutu („Pożeracz Zmarłych”), noszący też imiona Amam lub Ammit ${ }^{152}$ częściej jednak nazywany przez egiptologów Pożeraczką ${ }^{153}$ - który w czasie sądu pożera dusze tych, których serce okazuje się cięższe niż piórko Maat. ${ }^{154}$

Intrygujące, że tak popularny w Egipcie motyw karania przez smoki w zaświatach nie występuje w myśli greckiej. Chociaż przyznawano, że bogowie mogą posłużyć się potworami, aby ukarać ludzi, uznawano, że czynią to już w tym świecie. Represja ta mogła

145 KA, s. 73.

146 Tamże, s. 109-112.

${ }_{147}$ Tamże, s. 65; zob. AN, s. 142. Księga Amduat, Jedenasta godzina nocy, w: AN, s. 150-151; E. A. W a 11 is B u d ge, The Book of Gates, s. 235; por. AN, s. 174-175.

148 KA, s. 66-67.

149 Tamże, s. 74-75, 104-106, 132, 136, 146-148.

${ }^{150}$ E. A. Wa 11 i s B udge, The Book of Gates, s. 252; por. AN, s. 176.

151 Egipska nazwa Krainy Zmarłych, synonim Szetit.

${ }^{152}$ K. M i c hałow s k i, Nie tylko piramidy, s. 104.

${ }^{153}$ LM, s. 100.

154 AN, s. 282-283. 
być zesłana $\mathrm{z}$ różnych powodów: w wyniku sprzeciwienia się bogom, zemsty za znieważenie bóstwa lub jako wymierzenie sprawiedliwości. Pierwszą przyczynę podają mity o dwóch Smokach trojańskich, które zaatakowały Laokoona i jego synów. Kapłan sprowadził na siebie ten los, zgodnie z jednymi mitami, ostrzegając Trojan przed wciągnięciem w obręb miasta drewnianego konia, ${ }^{155}$ natomiast zgodnie z innymi, żeniąc się i płodząc dzieci z kobietą wybraną wbrew woli Apolla ${ }^{156}$ (chociaż niektórzy mitografowie podają, że był to znak mający ostrzec mieszkańców Ilionu przed koniem ${ }^{157}$ ). Karą za pychę z kolei była bestia etiopska zesłana przez Posejdona, po tym jak królowa tego regionu znieważyła jego córki, Nereidy, twierdząc, że ona $^{158}$ (bądź jej córka Andromeda ${ }^{159}$ ) przewyższa je urodą. Ten sam bóg zesłał także inne smoki na króla Troi Laomedona, odmawiającego mu zapłaty za zbudowanie murów miejskich. ${ }^{160}$ Karą mogło być jednak nie tylko zesłanie plagi smoków, ale także przemiana winnego w smoka (Kadmos $\left.{ }^{161}\right)$.

Jedyną bestią żyjącą w przekonaniu Greków w zaświatach był Cerber, który jednak nie pełnił funkcji kata dla dusz potępionych, a jedynie strzegł, by żadna z nich nie wydostała się z Hadesu. ${ }^{162}$ Podobnych strażników zaświatów odnaleźć możemy w tradycji egipskiej z tą różnicą, że broniły nie wyjścia lecz wejścia osobom niepowołanym, tj. grzesznikom lub nie znającym odpowiednich zaklęć. Jednym z takich smoków jest „Pożeracz Osła” gotów pożreć każdego grzesznika pragnącego wedrzeć się do raju. ${ }^{163}$ Innym, czekający na

${ }^{155}$ Publius Wergilius Maro, Eneida, 2.214-244.

$156 \mathrm{HF}, 135$.

${ }^{157}$ A p o 11 o d o r u s, Epitome, 5.17, http://www.perseus.tufts.edu/hopper/text? doc $=$ Perseus \%3Atext\%3A1999.01.0021\%3Atext\%3DEpitome\%3Abook\%3DE\%3A chapter\%3D5\%3Asection\%3D17 (dostęp: 27 X 2014).

$158 \mathrm{AL}, 2.4$.

$159 \mathrm{HF}, 64$.

160 Tamże, 89.

161 Tamże, 6.

${ }^{162} \mathrm{H}$ e z j o d, Teogonia, 769-774.

163 AN, s. 133-134. 
odpowiednie zaklęcie Ter, który zwojami swego cielska dwukrotnie zapieczętował ziemię, by chronić boga. ${ }^{164}$ Oprócz tego smoki strzegły także świętej drogi Re-stau (bezimienny ureusz i hybryda), komnaty Aheth (Hetch-nau) i drogi do niej (Amen), horyzontu w Amduat (Ankhaa-pau) czy wejścia do jego szóstego rejonu (bezimienny wąż). ${ }^{165}$

Smoki strzegły jednak nie tylko zaświatów, ale także świętych miejsc tu na ziemi, takich jak wyrocznia (której zgodnie z jedną wersją mitu strzegł Pyton), źródła (jednego z nich, należącego do Aresa strzegł jego syn Ismenios), gaje, nad którymi czuwali Smok nemejski i bezimienny smok, protoplasta Ofiogeników. ${ }^{166}$

Spośród innych zadań powierzanych smokom wymienić należy także te związane z transportem: noszenie bóstwa na grzbiecie lub ciągnięcie rydwanu, do którego ich zaprzężono albo stanowienie elementu łodzi. ${ }^{167}$ Także w pośredni sposób przez oświetlanie drogi słonecznej barce (i odstraszanie wrogów), wskazywanie drogi, lub umilanie jej przez śpiewanie i wysławianie bogów lub po prostu swoim towarzystwem. ${ }^{168}$

Smoki mogły także pełnić różnego rodzaju posługi (Tepan, $\left.\mathrm{Anzu}^{169}\right)$, także służąc jako ,przedmiot” tj. laskę-berło. Oprócz boga Słońca $\mathrm{Af}^{170}$ takie berło nosili także sokologłowi bogowie Tchatui, Meti, ludzcy Abenti, Benbeti, Sekhti, Sekhet. ${ }^{171}$ Motyw ten pojawia się także w mitologii greckiej, w przeciwieństwie jednak do egipskich odpowiedników smoki-węże nie stanowiły laski, lecz się wokół niej

${ }^{164}$ Tamże, s. 139; KA, s. 51.

${ }^{165}$ KA, s. 39-40, 48, 53. Czy podobną rolę odgrywa towarzyszka Amena, Hekent?; KA, s. 41-42.

${ }^{166} \mathrm{AL}, 1.4 ; 3.4 ; \mathrm{A}$ e $1 \mathrm{i}$ a n, On the characteristics of animals with an english translation by A. F. Scholfield, Books VI-XI 12.39; HF, 74.

167 KA, s. 17, 37, 42, 74-75, 131; AL, 1.5; D i o d or u s S i c u lu s, Library of History, 4.51.4; AL, 1.9.

${ }^{168}$ KA, s. 6, 8, 10, 12, 14, 19, 27-28, 39-40, 42, 73, 90-91, 94-95, 104-106, 120-121, 142-143.

169 Tamże, s. 48. Mit o ptaku Anzu, I, w: MA, s. 63.

${ }^{170}$ KA, s. 108-109.

171 Tamże, s. 8. 
owijały. Taki symbol dwóch węży owijających się wokół kija stał się atrybutem Hermesa, ale i heroldów jako takich, zaś z pojedynczym Asklepiosa. ${ }^{172}$

\section{Smoki i ludzie}

Relacje smoków z ludźmi nie ograniczały się do bycia ofiarami/ pogromcami. Część mitów, choć nie tak liczna, pokazuje, że te bestie nie tylko mogły udzielić pomocy ludziom, ale sprawdzały się także w roli towarzyszy, co prowadziło niekiedy do znaczenia bliższych, intymnych kontaktów, czego owocem było potomstwo przejawiające cechy obu gatunków.

Spośród pozytywnie przedstawionych smoków wymienić należy wspomnianego już Anzu, który w swojej sumeryjskiej wersji, mając związki z Enlilem i wpływ na przeznaczenie, udziela wsparcia królowi Lugalbandzie, zagubionemu w górach. Pragnąc odwdzięczyć się za nakarmienie pisklęcia i przystrojenie gniazda, odprowadza go do towarzyszy, obdarzając m.in. siłą i szybkością. ${ }^{173}$

Równie szczodry okazuje się także bezimienny smok egipski, opisany w Papirusie 1115, który zatroszczył się o rozbitka i umożliwił mu powrót do domu, obdarowując licznymi drogocennymi towarami i nie pragnąc niczego w zamian. ${ }^{174}$

Oswojenia stwora podjął się z kolei Kychreus, władca Salaminy. Jednakże w obliczu szkód czynionych przez smoka zmuszony był go odesłać do Demeter w Eleusis, która uczyniła go swoim towarzyszem. ${ }^{175}$ Podobny motyw istniał także w cyklu mitów dotyczących dwunastu prac Heraklesa. Zgodnie z jedną z wersji opowiadania, dotyczącego pokonania lwa nemejskiego, w walce wspomagał herosa smok, który karmiony przez niego towarzyszył mu aż do Teb. ${ }^{176}$ In-

\footnotetext{
${ }^{172}$ HA, 2.7. A p u l e j u s z, Metamorfozy albo złoty osiot, Gdańsk 2000, 1.4.

${ }^{173}$ Lugalbanda z Unug, w: ES, s. 39-46.

${ }^{174}$ Papirus 1115, w: Z. D r a p e 11 a, Od Lewiatana do Jormungarda, s. 139-140.

175 Strabo, Geography, 9.1.9.

176 Ptolemy Hephaestion, New History, 190.
} 
nemu sumeryjskiemu bohaterowi - Gilgameszowi - także asystował smok, wysłany przez Utu, by pilnował go w jaskiniach górskich w czasie jego podróży do Krainy Żyjących. ${ }^{177}$

Znacznie bliższe stosunki ze smokiem miała Halia, która udawszy się do świętego gaju Artemidy, strzeżonego przez tę bestię, rozkochała go w sobie i spała z nim, czego owocem była pierwsza generacja Ofiogeników. ${ }^{178}$ Podobna historia dotyczy także wspomnianego już Heraklesa, który, w zamian za odzyskanie koni, współżył ze Smoczycą scytyjską płodząc trzech synów - Agatyrsosa, Gelonosa i Skytesa, który został królem ziemi scytyjskiej i zapoczątkował dynastię jej władców. ${ }^{179}$

To powiązanie smoków i królów odnaleźć możemy także w innych mitach, z tą różnicą jednak, że władca nie miał wśród przodków smoka, lecz był połączeniem obu tych gatunków - homo dracens (pół-smokiem, pół-człowiekiem). Należą do nich Kekrops, pierwszy król Attyki, ${ }^{180}$ zarządca Beocji, założyciel Eleusis i Aten. ${ }^{181}$ A także jeden z kolejnych władców Aten, Erichtonios ${ }^{182}$ (aczkolwiek niektóre mity podają, że był zwykłym człowiekiem ${ }^{183}$ ). Podobny motyw odnaleźć możemy także w myśli bliskowschodniej, czego dowodem jest król o smoczym ciele Zahak, ${ }^{184}$, ,przez smoka urodzony” król Szulgi ${ }^{185}$ oraz Salmanasar III tytułujący się mianem „Wielkiego Smoka”. ${ }^{186}$

177 Gilgamesz i Huwawa, w: ES, s. 58-59.

${ }^{178} \mathrm{~S}$ t r a b o, Geography, 13.1; A e $1 \mathrm{i}$ a n, On the characteristics of animals with an english translation by A. F. Scholfield, Books VI-XI, 12.39.

${ }^{179} \mathrm{H}$ e r o d o t, Dzieje, 4.9.1.

180 AL, 3.14.

181 Strabo, Geography, 9.2.

$182 \mathrm{HF}, 166$.

183 AL, 3.14.

${ }^{184}$ M. S k ł a d a n k o w a, Mitologia Iranu, Mitologie świata, Warszawa 1989, s. 110 .

${ }^{185}$ Hymn na cześć Szulgi, w: M. B i e l i c k i, Zapomniany świat Sumerów, Warszawa 1966, s. 148.

186 Shalmaneser III, The fight against the aramean coalition, 1, w: ANET, s. 302. Dotyczyło to także bogów; Zwycięskie walki Ninurty z Górą, w: MS, s. 142. 
Swoje pochodzenie od smoków wykazywali jednak nie tylko królowie, ale także całe grupy ludzi - oprócz wspomnianych już Ofiogeników byli to także bardziej znani Spartanie. Zgodnie bowiem z cyklem mitów o Kadmosie, po pokonaniu smoka Ismeniosa, bohater, za radą bogini, posiał w ziemi jego zęby. Wyrosła z nich armia mężczyzn w pełnym rynsztunku, którzy rzucili się do bratobójczej walki. Przeżyło ją pięciu - Chtonios, Udajos, Peloros, Hyperenor i Echion ${ }^{187}$ - protoplaści Spartan. ${ }^{188}$

$$
* * *
$$

Zarysowujące się w ten sposób bogactwo przedstawień i wykorzystania tego motywu zaskakuje swoją różnorodnością, choć zaczerpnięte jest tylko z wąskiego wycinka dziejów ludzkości. Rodzi to kolejne pytania: Czy z podobnymi przedstawieniami możemy spotkać się w dorobku innych kultur? Czy też pojawiają się w nich nietypowe, oryginalne wątki? Zwłaszcza zaś czy i na ile ludzie, którzy tworzyli Pismo Święte korzystali z tego dorobku? Zważywszy zarówno na powszechność tego motywu - prawie każdy kontynent ma własne smocze opowieści - jak i kilkanaście tysięcy lat tradycji, mitologicznej i religijnej, wieki nauk przyrodniczych oraz tysiące dzieł sztuki przed każdym człowiekiem chcącym zajmować się tą tematyką otwiera się niesamowicie obszerne i bogate pole badawcze.

Anna KRYZA

Słowa kluczowe: smoki, mitologia, charakterystyka smoka, konflikt smoka z bogami i ludźmi, relacje smoka z bogami/ludźmi, Bóg-smok

Keywords: dragons, mythology, the characteristics of the dragon, dragon's conflict with the gods and humans, dragon's relationship with the gods/ people, God-dragon

187 AL, 3.4.

${ }^{188}$ Por. J.-P. V e r n a n t, Mity greckie, czyli świat, bogowie, ludzie, s. 127. 


\section{Ancient Dracology. The Dragon motif in extrabiblical literature}

Summary

The article focuses on dragons and their role in ancient Roman, Greek, Egyptian and Middle Eastern cultures. By analyzing their appearance in texts, the division into two main groups is made: the characteristic of dragons and the function of the dragon motif. This may help in understanding the origins, place and function of dragon motifs in the Bible. 